\title{
Calculation and Analysis of Carbon Emissions for Green Buildings During Operation Period in Beijing
}

\author{
Guojian WANG ${ }^{1}$ \\ Beijing Institute of Residential Building Design \& Research Co.,Ltd,Beijing,100005,China
}

\begin{abstract}
This study analyzed the carbon emissions for two-star green residential buildings in Beijing. During operation period, the carbon emissions were calculated for air-conditioning, heating, lighting, elevator, and domestic hot water systems. Furthermore, the carbon emissions for full life cycle are also given in this paper based on the statistical method of big data. The results show that the carbon emissions during operation and full life cycle periods were 17 21 and 21 27 $\mathrm{kgCO}_{2} \mathrm{e} /\left(\mathrm{m}^{2} \cdot \mathrm{a}\right)$, respectively. During operation period, the air-conditioning and heating systems accounted for $60 \% \sim 70 \%$ of the total carbon emissions, $26 \% \sim 30 \%$ and $4 \% \sim 9 \%$ for lighting and elevator systems, and the carbon emissions were lowest for domestic hot water systems.
\end{abstract}

Keywords: Green building, carbon emission, operation period, calculation, analysis

\section{Introduction}

In response to global climate change, the Chinese government has set a target of reaching a peak in carbon dioxide emissions around 2030 and striving to be carbon neutrality by 2060. The extensively implement of green buildings is an effect way to reach the target of the peak carbon dioxide emissions and carbon neutrality.

Most of existed studies conducted by Chinese researchers on building carbon emissions during full or partial operation periods were based on life cycle assessment theory. Jin [1] analyzed the main influence factors on the variations of energy consumption in residential environments by using analytic hierarchy process (AHP), based on the established model related to energy-saving building, the concept of building carbon emission per person was also put forward. Liu [2] combined computational simulation and mathematical model to quantitively analyze the emission-reduction effect in low-carbon residential building in hot summer and warm winter area respectively during construction and operation periods. Verbeeck et al. [3] calculated and analyzed the energy consumption and carbon emissions of full life cycle for 5 residential buildings with different building structures in Belgium, then the carbon emission list and model were further established. Gustavsson et al. [4] utilized emission coefficients to calculate the carbon emissions in every stage of buildings' full life cycle, and took a wooden residential building as an example to determine the energy consumption and carbon

${ }^{1}$ Corresponding author: Guojian Wang, Beijing Institute of Residential Building Design \& Research Co., Ltd, Beijing, 100005, China; E-mail: wgj86365413@126.com. 
emissions.

Unfortunately, the factors that influence building energy consumption such as heating load, cooling load, and power consumption were more emphasized in the processes of traditional design and consultant, while the carbon emissions factors were not further analyzed, leading to relatively less known on carbon emissions for green buildings. Therefore, this paper calculated and analyzed the monitored data of carbon emissions for air conditioning, heating, lighting, elevator, and domestic hot water systems during operation period in 3 green buildings. The relationship of carbon emissions between operation period and full life cycle period was obtained by using the statistical method of big data, furthermore, the carbon intensity for full life cycle can be acquired. This study aims to provide basic data and references for relevant studies.

\section{Project Overview}

3 two-star green residential buildings were selected to analyze, and the detailed information of the 3 buildings are summarized in table 1 .

Table 1. Detailed information of 3 residential buildings.

\begin{tabular}{|c|c|c|c|c|c|c|}
\hline No. & Location & $\begin{array}{c}\text { Building } \\
\text { area } \\
\left(\mathrm{m}^{2}\right)\end{array}$ & $\begin{array}{l}\text { Building } \\
\text { height } \\
\text { (m) }\end{array}$ & Floor & $\begin{array}{l}\text { Air conditioning } \\
\text { and heating } \\
\text { systems }\end{array}$ & $\begin{array}{l}\text { Performance of } \\
\text { main equipment }\end{array}$ \\
\hline $1 \#$ & $\begin{array}{l}\text { Fengtai } \\
\text { district, } \\
\text { Beijing }\end{array}$ & 20811 & 79.8 & $\begin{array}{l}28 \text { floors } \\
\text { above the } \\
\text { ground and } 4 \\
\text { floors } \\
\text { underground }\end{array}$ & $\begin{array}{l}\text { Cooling with } \\
\text { wall-mounted } \\
\text { split air } \\
\text { conditioners, } \\
\text { radiant floor } \\
\text { heating system } \\
\text { with central gas } \\
\text { boiler }\end{array}$ & $\begin{array}{l}\text { The energy } \\
\text { efficiency ratio of } \\
\text { air conditioner is } \\
3.4 \text {, the thermal } \\
\text { efficiency of the } \\
\text { boiler is } 90 \%\end{array}$ \\
\hline $2 \#$ & $\begin{array}{l}\text { Shunyi } \\
\text { district, } \\
\text { Beijing }\end{array}$ & 4802 & 27.6 & $\begin{array}{l}9 \text { floors above } \\
\text { the ground and } \\
2 \text { floors } \\
\text { underground }\end{array}$ & $\begin{array}{l}\text { Cooling with } \\
\text { wall-mounted } \\
\text { split air } \\
\text { conditioners, } \\
\text { radiant floor } \\
\text { heating system } \\
\text { with wall- } \\
\text { mounted gas } \\
\text { boiler }\end{array}$ & $\begin{array}{l}\text { The energy } \\
\text { efficiency ratio of } \\
\text { air conditioner is } \\
3.4 \text {, the thermal } \\
\text { efficiency of the } \\
\text { boiler is } 84 \%\end{array}$ \\
\hline $3 \#$ & $\begin{array}{l}\text { Pinggu } \\
\text { district, } \\
\text { Beijing }\end{array}$ & 9668 & 48 & $\begin{array}{l}16 \text { floors } \\
\text { above the } \\
\text { ground and } 2 \\
\text { floors } \\
\text { underground }\end{array}$ & $\begin{array}{l}\text { Cooling with } \\
\text { wall-mounted } \\
\text { split air } \\
\text { conditioners, } \\
\text { radiant floor } \\
\text { heating system } \\
\text { with municipal } \\
\text { heating }\end{array}$ & $\begin{array}{l}\text { The energy } \\
\text { efficiency ratio of } \\
\text { air conditioner is } \\
3.4 \text {, the supply } \\
\text { (return) water for } \\
\text { municipal heating } \\
\text { and residents are } \\
110(70){ }^{\circ} \mathrm{C} \text { and } 50 \\
(40){ }^{\circ} \mathrm{C}\end{array}$ \\
\hline
\end{tabular}




\section{Calculation and Analysis}

\subsection{Determination of Boundary Condition}

The cooling and heating loads of the 3 buildings were simulated by DeST software. The heating period was from 15th November to 15th March of the next year, and the cooling period was from first June to 31th August. The indoor design parameters are shown in table 2 .

Table 2. Indoor design parameters.

\begin{tabular}{ccccc}
\hline \multirow{2}{*}{ Room type } & \multicolumn{2}{c}{ Summer } & \multicolumn{2}{c}{ Winter } \\
& Temperature $\left({ }^{\circ} \mathrm{C}\right)$ & $\begin{array}{c}\text { Relative humidity } \\
(\%)\end{array}$ & Temperature $\left({ }^{\circ} \mathrm{C}\right)$ & $\begin{array}{c}\text { Relative humidity } \\
(\%)\end{array}$ \\
\hline Living room & 26 & 65 & 20 & 30 \\
Bedroom & 26 & 65 & 20 & 30 \\
Kitchen and & 26 & 65 & 20 & - \\
bathroom & - & - & - & - \\
Stairwell & & &
\end{tabular}

\subsection{Energy Consumption Calculations for Different Buildings}

\section{(1) Building 1\#}

a) Calculations of energy consumption for air conditioning and heating systems

According to the simulated results of building 1\#, the cooling and heating loads were 293.55 MWh and 497.92 MWh, respectively, and the convey efficiency was 0.93 for outdoor pipes [5]. The total energy consumption for cooling with air conditioners and heating was $86.33 \mathrm{MWh} / \mathrm{a}$ and $595 \mathrm{MWh} / \mathrm{a}$, respectively, corresponding to 4.71 $\mathrm{kWh} /\left(\mathrm{m}^{2} \cdot \mathrm{a}\right)$ power and $3.4 \mathrm{Nm}^{3} /\left(\mathrm{m}^{2} \cdot \mathrm{a}\right)$ natural gas. The carbon emission factor was 2.16 $\mathrm{kgCO}_{2} \mathrm{e} / \mathrm{Nm}^{3}$ for natural gas [6], and the carbon emission factor was $0.604 \mathrm{kgCO}_{2} \mathrm{e} / \mathrm{kWh}$ for electric power in Beijing [7]. Therefore, the total carbon emission for cooling and heating systems in building $1 \#$ was $10.18 \mathrm{kgCO}_{2} \mathrm{e} /\left(\mathrm{m}^{2} \cdot \mathrm{a}\right)$.

b) Calculation of energy consumption for lighting system

Based on the Standard for building carbon emission calculation GBT513662019 , the current limitation values for lighting power and lighting time in the 3 residential building were determined and shown in table 3.

Table 3. The limitations for lighting power and lighting time in the 3 residential buildings.

\begin{tabular}{ccc}
\hline Room type & Lighting time within a month $(\mathrm{h})$ & Lighting power density $\left(\mathrm{W} / \mathrm{m}^{2}\right)$ \\
Living room & 165 & 6 \\
Bedroom & 135 & 6 \\
Kitchen & 96 & 6 \\
Bathroom & 165 & 6 \\
Public space such as corridor, etc. & 5 & 15 \\
\hline
\end{tabular}

The calculated results showed that the total energy consumption for lighting system in building 1\# was $8.66 \mathrm{kWh} /\left(\mathrm{m}^{2} \cdot \mathrm{a}\right)$ throughout a year, and the corresponding carbon emission was $5.23 \mathrm{kgCO}_{2} \mathrm{e} /\left(\mathrm{m}^{2} \cdot \mathrm{a}\right)$.

c) Calculation of energy consumption for elevator

According to the predictive model of energy consumption for elevator which has been provided in the Specification for electric lifts GB/T10058-2009, the energy 
consumption for elevator can be calculated by equation (1).

$$
E_{e l}=\left(K_{1} \times K_{2} \times K_{3} \times H \times F \times P\right) /(V \times 3600)+E s t
$$

Where $E_{e l}$ is the energy consumption for elevator throughout a year, $\mathrm{kWh} / \mathrm{a} ; K_{l}$ is the driving coefficient, $K_{l}=1.6$ (driven by ACVV system), $K_{l}=1.0$ (driven by VVF system), $K_{l}=0.6$ (driven by VVF system with energy feedback); $K_{2}$ is the average travel distance coefficient, $K_{2}=1.0$ (two floors), $K_{2}=0.5$ (more than two floors with single elevator or two elevators parallel operation), $K_{2}=0.3$ (no less than two elevators and with group control); $K_{3}$ is the average load coefficient of elevator car, $K_{3}=0.35 ; H$ is the longest travel distance, $\mathrm{m} ; F$ is the yearly number of starting times, based on the references on normal residential building, herein, $F$ is about 146000 times; $P$ is rated power, $\mathrm{kW} ; V$ is rated speed, $\mathrm{m} / \mathrm{s} ;$ Est is the yearly total energy consumption of idle state, which is about account for $70 \%$ of total energy consumption.

Building 1\# had 2 dwelling units and 4 elevators, all elevators were driven by VVF system. For each elevator, the rated load was $825 \mathrm{~kg}$, the longest travel distance was $80 \mathrm{~m}$, and the rated speed was $2 \mathrm{~m} / \mathrm{s}$. According to equation (1), the yearly energy consumption for the elevators in building $1 \#$ can be calculated, corresponding to $2.53 \mathrm{kWh} /\left(\mathrm{m}^{2} \cdot \mathrm{a}\right)$ and $1.53 \mathrm{kgCO}_{2} \mathrm{e} /\left(\mathrm{m}^{2} \cdot \mathrm{a}\right)$.

d) Calculation of energy consumption for domestic hot water system

The energy consumption of domestic hot water system in residential building should be analyzed based on the actual operation condition and that can be calculated by equations (2) and (3):

$$
\begin{gathered}
Q_{r p}=4.178 \frac{m q_{r}\left(t_{r}-t_{l}\right) \rho_{r}}{1000} \\
Q_{r}=T Q_{r p}
\end{gathered}
$$

Where $Q_{r}$ is the yearly energy consumption of domestic hot water system, $(\mathrm{kWh} / \mathrm{a})$; $Q_{r p}$ is hourly energy consumption of domestic hot water system, $(\mathrm{kW} / \mathrm{h}) ; m$ is the unit of water consumption; $q_{r}$ is the limitation of domestic hot water for each people (L/person), which can be determined by the Standard for water saving design in civil building GB50555-2010; $\rho_{r}$ is the density of domestic hot water $(\mathrm{kg} / \mathrm{L}) ; t_{r}$ is the design temperature of domestic hot water $\left({ }^{\circ} \mathrm{C}\right)$; $t_{l}$ is the design temperature of cold water $\left({ }^{\circ} \mathrm{C}\right)$.

$20 \mathrm{~L} /$ person domestic hot water was used in this study. According to the Standard for design of building water supply and drainage GB50015-2019, the design temperature of cold water is $4{ }^{\circ} \mathrm{C}$. Therefore, the yearly energy consumption of domestic hot water system was $399.4 \mathrm{kWh} / \mathrm{a}$, corresponding to $0.022 \mathrm{kWh} /\left(\mathrm{m}^{2} \cdot \mathrm{a}\right)$, and the carbon emission of domestic hot water in building 1 \# was $0.013 \mathrm{kgCO}_{2} \mathrm{e} /\left(\mathrm{m}^{2} \cdot \mathrm{a}\right)$.

In summary, the carbon emission for building $1 \#$ during operation period was 16.95 $\mathrm{kgCO}_{2} \mathrm{e} / \mathrm{m}^{2}$.

\section{(2) Building 2\#}

a) Calculations of energy consumption for air conditioning and heating systems

According to the simulated results of building 2\#, the cooling and heating loads for building 2\# were 61.52 MWh and 149.34 MWh, respectively, and the convey efficiency was 0.93 for outdoor pipes. The total energy consumption for cooling and heating systems were $18.09 \mathrm{MWh} / \mathrm{a}$ and $177.78 \mathrm{MWh} / \mathrm{a}$, respectively, corresponding to 4.18 
$\mathrm{kWh} /\left(\mathrm{m}^{2} \cdot \mathrm{a}\right)$ electric power and $4.29 \mathrm{Nm}^{3} /\left(\mathrm{m}^{2} \cdot \mathrm{a}\right)$ natural gas. The carbon emission factor for natural gas was $2.16 \mathrm{kgCO}_{2} \mathrm{e} / \mathrm{Nm}^{3}$, and the carbon emission factor for electric power in Beijing was $0.604 \mathrm{kgCO}_{2} \mathrm{e} / \mathrm{kWh}$. Therefore, the total carbon emission of cooling and heating systems for building $2 \#$ was $11.79 \mathrm{kgCO}_{2} \mathrm{e} /\left(\mathrm{m}^{2} \cdot \mathrm{a}\right)$.

b) Calculation of energy consumption for lighting system

The calculated results showed that the total energy consumption for lighting system in building 2\# was $9.83 \mathrm{kWh} /\left(\mathrm{m}^{2} \cdot \mathrm{a}\right)$ throughout a year, and the corresponding carbon emission was $5.94 \mathrm{kgCO}_{2} \mathrm{e} /\left(\mathrm{m}^{2} \cdot \mathrm{a}\right)$.

c) Calculation of energy consumption for elevator

Building 2\# had 2 dwelling units and 2 elevators, both of the elevators were driven by VVF system. For each elevator, the rated load was $1000 \mathrm{~kg}$, the longest travel distance was $30 \mathrm{~m}$, and the rated speed was $2 \mathrm{~m} / \mathrm{s}$. According to equation (1), the yearly energy consumption for the elevators in building $2 \#$ can be calculated, corresponding to 2.01 $\mathrm{kWh} /\left(\mathrm{m}^{2} \cdot \mathrm{a}\right)$ and $1.21 \mathrm{kgCO}_{2} \mathrm{e} /\left(\mathrm{m}^{2} \cdot \mathrm{a}\right)$.

d) Calculation of energy consumption for domestic hot water system

The yearly energy consumption of domestic hot water system in building $2 \#$ was $59.9 \mathrm{kWh} / \mathrm{a}$, corresponding to $0.014 \mathrm{kWh} /\left(\mathrm{m}^{2} \cdot \mathrm{a}\right)$, and the carbon emission of domestic hot water in building $2 \#$ was $0.0085 \mathrm{kgCO}_{2} \mathrm{e} /\left(\mathrm{m}^{2} \cdot \mathrm{a}\right)$.

In summary, the total carbon emission for building $2 \#$ during operation period was $18.95 \mathrm{kgCO} 2 \mathrm{e} / \mathrm{m} 2$.

\section{(3) Building 3\#}

a) Calculation of energy consumption for air conditioning and heating systems

According to the simulated results of building $3 \#$, the cooling and heating loads were 155.58 MWh and 262.82MWh, respectively, and the convey efficiency was 0.93 for outdoor pipes. The energy consumption for cooling with air conditioners and heating were $45.8 \mathrm{MWh} / \mathrm{a}$ and $105.0 \mathrm{MWh} / \mathrm{a}$, respectively, corresponding to $4.73 \mathrm{kWh} /\left(\mathrm{m}^{2} \cdot \mathrm{a}\right)$ electric power. The carbon emission factor of thermal energy was $110 \mathrm{kgCO}_{2} \mathrm{e} / \mathrm{GJ}$ [8]. The total carbon emission of cooling and heating systems in building 3\# was 14.4 $\mathrm{kgCO}_{2} \mathrm{e} /\left(\mathrm{m}^{2} \cdot \mathrm{a}\right)$.

b) Calculation of energy consumption for lighting system

The calculated results showed that the total energy consumption for lighting system throughout a year in building $3 \#$ was $9.01 \mathrm{kWh} /\left(\mathrm{m}^{2} \cdot \mathrm{a}\right)$, and the corresponding carbon emission was $5.42 \mathrm{kgCO}_{2} \mathrm{e} /\left(\mathrm{m}^{2} \cdot \mathrm{a}\right)$.

c) Calculation of energy consumption for elevator

Building $3 \#$ had 2 dwelling units and 4 elevators, all elevators were driven by VVF system. For each elevator, the rated load was $1000 \mathrm{~kg}$, the longest travel distance was $48 \mathrm{~m}$, and the rated speed was $2 \mathrm{~m} / \mathrm{s}$. According to equation (1), the yearly energy consumption for the elevators in building $1 \#$ can be calculated, corresponding to 1.518 $\mathrm{kWh} /\left(\mathrm{m}^{2} \cdot \mathrm{a}\right)$ and $0.91 \mathrm{kgCO}_{2} \mathrm{e} /\left(\mathrm{m}^{2} \cdot \mathrm{a}\right)$.

d) Calculation of energy consumption for elevator domestic hot water system

The yearly energy consumption of domestic hot water system in building 3\# was $228.22 \mathrm{kWh} / \mathrm{a}$, corresponding to $0.023 \mathrm{kWh} /\left(\mathrm{m}^{2} \cdot \mathrm{a}\right)$, and the carbon emissions of domestic hot water in building $3 \#$ was $0.014 \mathrm{kgCO}_{2} \mathrm{e} /\left(\mathrm{m}^{2} \cdot \mathrm{a}\right)$.

In summary, the total carbon emission in building $1 \#$ during operation period was $20.74 \mathrm{kgCO}_{2} \mathrm{e} / \mathrm{m}^{2}$. 


\subsection{Comparison and Analysis of the 3 Buildings}

a) Summary of the carbon emissions in 3 buildings

The calculated results of different buildings are summarized in figure 1 and table $4 \sim$ table 6 , the results showed that:

1) The carbon emissions of different buildings ranged from $17 \sim 21 \mathrm{kgCO}_{2} \mathrm{e} /\left(\mathrm{m}^{2} \cdot \mathrm{a}\right)$.

2) The cooling and heating systems accounted for $60 \% \sim 70 \%$ of total carbon emissions, and it was $26 \% \sim 30 \%$ for lighting system, $4 \% \sim 9 \%$ for elevators, while the proportion of domestic hot water system was the lowest.

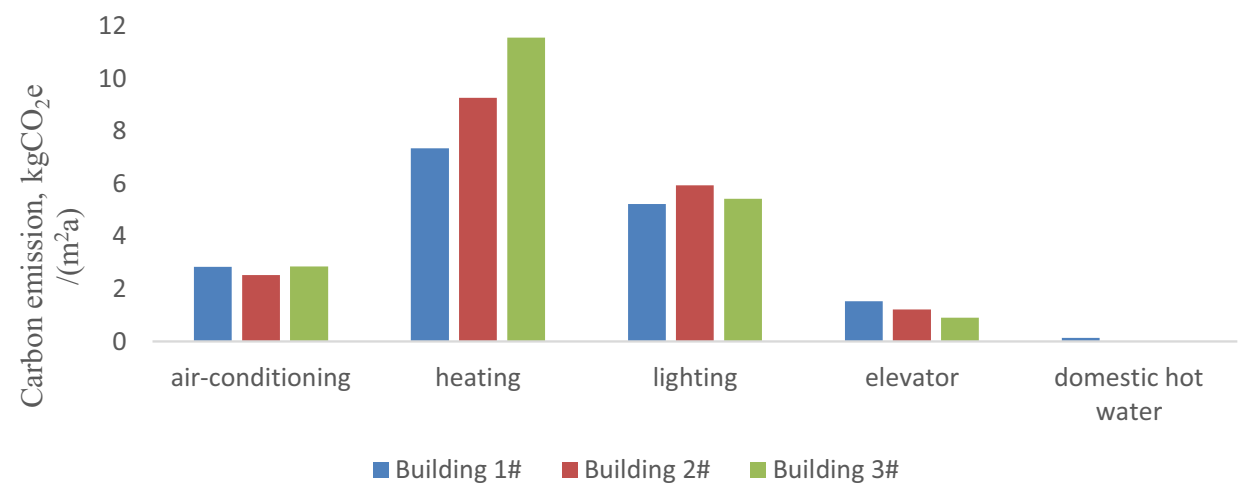

Figure 1. The carbon emissions for different systems in 3 buildings.

Table 4. The calculated results of building 1\#.

\begin{tabular}{cccc}
\hline No. & System & $\mathrm{kgCO}_{2} \mathrm{e} /\left(\mathrm{m}^{2} \cdot \mathrm{a}\right)$ & Proportion \\
\hline 1 & Air conditioning & 2.84 & $16.76 \%$ \\
2 & Heating & 7.34 & $43.30 \%$ \\
3 & Lighting & 5.23 & $30.86 \%$ \\
4 & Elevator & 1.53 & $9.03 \%$ \\
5 & Domestic hot water & 0.13 & $0.77 \%$ \\
Total & & 16.95 & \\
\hline
\end{tabular}

Table 5. The calculated results of building 2\#.

\begin{tabular}{cccc}
\hline No. & System & $\mathrm{kgCO}_{2} \mathrm{e} /\left(\mathrm{m}^{2} \cdot \mathrm{a}\right)$ & Proportion \\
\hline 1 & Air conditioning & 2.52 & $13.30 \%$ \\
2 & Heating & 9.27 & $48.92 \%$ \\
3 & Lighting & 5.94 & $31.35 \%$ \\
4 & Elevator & 1.21 & $6.39 \%$ \\
5 & Domestic hot water & 0.0085 & $0.044 \%$ \\
Total & & 18.95 & \\
\hline
\end{tabular}


Table 6. The calculated results of building $3 \#$.

\begin{tabular}{cccc}
\hline No. & System & $\mathrm{kgCO}_{2} \mathrm{e} /\left(\mathrm{m}^{2} \cdot \mathrm{a}\right)$ & Proportion \\
\hline 1 & Air conditioning & 2.85 & $13.74 \%$ \\
2 & Heating & 11.55 & $55.69 \%$ \\
3 & Lighting & 5.42 & $26.13 \%$ \\
4 & Elevator & 0.91 & $4.38 \%$ \\
5 & Domestic hot water & 0.014 & $0.068 \%$ \\
Total & & 20.74 & \\
\hline
\end{tabular}

b) Analysis of carbon emissions of air conditioning and heating systems

The carbon emissions of different heating sources are shown in table 7. The carbon emissions present regional central gas boiler $<$ wall-mounted gas boiler $<$ municipal heating. The thermal sources of municipal heating are mainly provided by combined heat and power (CHP) or central boiler, to reduce the carbon emissions, the use of clean energy and the types of energy should be enhanced. The carbon emissions of air conditioning system mainly ranged from 2 to $3 \mathrm{kgCO}_{2} \mathrm{e} /\left(\mathrm{m}^{2} \cdot \mathrm{a}\right)$.

Table 7. Carbon emissions of air conditioning and heating systems.

\begin{tabular}{|c|c|c|c|}
\hline No. & Air conditioning and heating systems & Performance of main equipment & $\begin{array}{c}\text { Carbon } \\
\text { emission } \\
\mathrm{kgCO}_{2} \mathrm{e} /\left(\mathrm{m}^{2} \cdot \mathrm{a}\right) \\
\end{array}$ \\
\hline 1 & $\begin{array}{l}\text { Radiant floor heating system with central } \\
\text { gas boiler }\end{array}$ & $\begin{array}{l}\text { The thermal efficiency of the boiler } \\
\text { is } 90 \%\end{array}$ & 7.34 \\
\hline 2 & $\begin{array}{l}\text { Cooling with wall-mounted split air } \\
\text { conditioners, radiant floor heating } \\
\text { system with wall-mounted gas boiler }\end{array}$ & $\begin{array}{l}\text { the thermal efficiency of the boiler is } \\
84 \%\end{array}$ & 9.27 \\
\hline 3 & $\begin{array}{l}\text { Cooling with wall-mounted split air } \\
\text { conditioners, radiant floor heating } \\
\text { system with municipal heating }\end{array}$ & $\begin{array}{l}\text { The supply (return) water for } \\
\text { municipal heating and residents } \\
\text { were } 110(70){ }^{\circ} \mathrm{C} \text { and } 50(40){ }^{\circ} \mathrm{C}\end{array}$ & 11.55 \\
\hline
\end{tabular}

c) Carbon emissions of full life cycle

Referring to the building carbon emissions reported by different studies [9-13], the carbon emissions during operating period accounted for $70 \% \sim 90 \%$ of total carbon emissions within full life cycle. In terms of this study, the building carbon emissions of full life cycle were $21 \sim 27 \mathrm{kgCO}_{2} \mathrm{e} /\left(\mathrm{m}^{2} \cdot \mathrm{a}\right)$.

\section{Conclusions}

(1) The buildings' carbon emissions during operation period and full life cycle were 17 21 and 21 27 $\mathrm{kgCO}_{2} \mathrm{e} /\left(\mathrm{m}^{2} \cdot \mathrm{a}\right)$, respectively.

(2) The cooling and heating systems accounted for $60 \% \sim 70 \%$ of total carbon emissions, and it was $26 \% \sim 30 \%$ for lighting system, $4 \% \sim 9 \%$ for elevators, while the proportion of domestic hot water system was the lowest, less than $1 \%$.

(3) The carbon emissions of air conditioning system during operation period mainly ranged from 2 to $3 \mathrm{kgCO}_{2} \mathrm{e} /\left(\mathrm{m}^{2} \cdot \mathrm{a}\right)$.

(4) The carbon emissions present regional central gas boiler $<$ wall-mounted gas boiler $<$ municipal heating. 


\section{List of notations}

$E_{e l}$ is the energy consumption for elevator throughout a year

$K_{l}$ is the driving coefficient of elevator

$K_{2}$ is the average travel distance coefficient of elevator

$K_{3}$ is the average load coefficient of elevator car of elevator

$H$ is the longest travel distance of elevator

$F$ is the yearly number of starting times of elevator

$P$ is rated power of elevator

$V$ is rated speed of elevator

Est is the yearly total energy consumption of idle state

$Q_{r}$ is the yearly energy consumption of domestic hot water system

$Q_{r p}$ is hourly energy consumption of domestic hot water system

$m$ is the unit of water consumption

$q_{r}$ is the limitation of domestic hot water for each people

$\rho_{r}$ is the density of domestic hot water

$t_{r}$ is the design temperature of domestic hot water

$t_{l}$ is the design temperature of cold water

\section{References}

[1] Jin J. Energy efficiency in residential building research based on carbon emissions. 2014; Changan University.

[2] Liu J. Quantified study on $\mathrm{CO}_{2}$ reduction effect of low-carbon housing technology in hot summer and cold winter zone. 2014. Huazhong University of Science and Technology.

[3] Verbeeck G, Hens H. Life cycle inventory of buildings: A calculation method. Building and Environment. 2010; 45(4):1037-41.

[4] Gustavsson L, Joelsson A, Sathre R. Life cycle primary energy use and carbon emission of an eight-storey wood-framed apartment building. Energy and Buildings. 2010; 42(2):230-42.

[5] Design standard for energy efficiency of residential buildings DB11/891-2020.

[6] Technical Guidelines for Assessment of Low-carbon Building Operation DB11/T 1420_2017.

[7] Requirements for carbon dioxide emission accounting and reporting Power generation enterprises DB11/T $1781-2020$.

[8] Requirements for carbon dioxide emission accounting and reporting Heat production and supply enterprises DB11/T $1784-2020$.

[9] Peng B 2012 Case Study on Life Cycle Energy Consumption and $\mathrm{CO}_{2}$ Emissions of Green Buildings Tsinghua University.

[10] Chen S, Cui D, Zhang H. Calculation of carbon dioxide emissions from buildings and case study. Journal of Beijing University of Technology. 2016; 42(04):594-600.

[11] Wang Y, Yang X, Yan H, Zhang Y, Li J. Carbon emission accounting for buildings based on whole life cycle: A case study of reconstruction project at college in guangzhou. Journal of Engineering Management. 2017; 31(03):19-24.

[12] Li J, Liu Y. The carbon emission accounting model based on building lifecycle. Journal of Engineering Management. 2015; 29(04):12-16.

[13] Yu J, Zhang Y, Qi S. Study on carbon emission characteristics and emission reduction strategies of public buildings in the hot summer and warm winter areas throughout their life cycles - Take Xiamen city as an example. Building Science. 2014; 30(02): 13-8. 